\title{
e Protocol for Evaluation of the Comparative Effectiveness of Percutaneous Adhesiolysis and Caudal Epidural Steroid Injections in Low Back and/or Lower Extremity Pain without Post Surgery Syndrome or Spinal Stenosis
}

Laxmaiah Manchikanti, MD, Vidyasagar Pampati, MSc, and Kimberly A. Cash, RT

From: Pain Management Center of Paducah, Paducah, KY

Dr. Manchikanti is Medical Director of the Pain Management Center of Paducah, Paducah,

$\mathrm{KY}$, and Associate Clinica

Professor of Anesthesiology and Perioperative Medicine,

University of Louisville, Louisville, KY.

Mr. Pampati is a Statistician at the Pain Management Center of

Paducah, Paducah, KY.

Mrs. Cash is a Research

Coordinator at the Pain Management Center of Paducah, Paducah, KY.

Address correspondence: Laxmaiah Manchikanti, MD 2831 Lone Oak Road

Paducah, Kentucky 42003 E-mail:drlm@thepainmd.com

Disclaimer: There was no external funding in the preparation of this manuscript.

Conflict of interest: None.

Manuscript received 03/01/2010

Accepted for publication: 03/12/2010

Free full manuscript: www.painphysicianjournal.com
Background: Treatment of chronic low back pain with or without lower extremity pain continues to be a challenge. Epidural steroids are commonly utilized in patients after the failure of conservative treatment. The results of epidural steroid injections have been variable based on the pathophysiology, the route of administration, injected drugs, and utilization of fluoroscopy. In patients resistant to fluoroscopically directed epidural injections, percutaneous epidural adhesiolysis and percutaneous targeted delivery of injections with or without adhesiolysis has been recommended. Percutaneous adhesiolysis has been studied in chronic pain syndromes related to post laminectomy syndrome and spinal stenosis with encouraging results

There is a paucity of literature regarding the effectiveness of the targeted delivery of medications with or without epidural adhesiolysis in patients recalcitrant to epidural steroid injections without a history of surgery and spinal stenosis.

Study Design: A randomized, equivalence trial of percutaneous lumbar adhesiolysis and caudal epidural steroid injections in patients with low back and/or lower extremity pain without post surgery syndrome or spinal stenosis.

Setting: An interventional pain management practice setting in the United States.

Objective: The study is designed to evaluate the effectiveness of percutaneous epidural adhesiolysis in managing chronic low back and/or lower extremity pain in patients without post lumbar surgery syndrome or spinal stenosis and compare it with fluoroscopically directed caudal epidural steroid injections

Methods: The study design includes 120 patients randomly assigned into 2 groups. Group I (60 patients), the control group, will receive caudal epidural injections with catheterization up to $\$ 3$ with local anesthetic, steroids, and $0.9 \%$ sodium chloride solution; Group II (60 patients), the intervention group, will receive percutaneous adhesiolysis with target delivery of lidocaine, $10 \%$ hypertonic sodium chloride solution, and non-participate betamethasone. Randomization will be performed by computer-generated random allocation sequence by simple randomization.

Outcome Measures: Multiple outcome measures will be utilized including numeric rating scale (NRS), the Oswestry Disability Index $2.0(\mathrm{ODI})$, employment status, and opioid intake with assessment at 3, 6, 12, 18 and 24 months post treatment.

Significant pain relief is considered as $50 \%$ or more, whereas significant improvement in the disability score is defined as a reduction of $40 \%$ or more.

Results: The results will be analyzed to show significant relief as well as improvement in functional status.

Limitations: This study is limited by potentially inadequate double blinding and the lack of a placebo group. 
Conclusion: This protocol describes a comparative effectiveness evaluation of percutaneous adhesiolysis and epidural steroid injections in managing chronic low back and lower extremity pain in patients without post surgery syndrome or spinal stenosis utilizing a randomized, equivalence trial design.

Clinical Trial Registration: NCT01053273

Key words: Chronic low back pain, disc herniation, post lumbar surgery syndrome, spinal stenosis, epidural steroid injections, percutaneous adhesiolysis, randomized trial, comparative effectiveness

\section{Pain Physician 2010; 13:E91-E110}

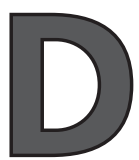
espite advances in biomedical knowledge and the highest per capita health care expenditures in the world, the quality and outcome of health care vary dramatically across the United States (1-8). Accordingly, the trend to develop and implement research and support of evidence-based practice has been a focus of medical practice for the past decade. As an emerging specialty, interventional pain management faces multiple problems which may be disproportionate compared to established medical specialties. Interventional pain management is faced with the task of increasing appropriate utilization of effective, safe techniques due to its emerging nature, as well as eliminating potentially inappropriate care that may be ineffective or unsafe $(5,6,8-16)$. The available evidence at the present time documents a wide degree of variance in the definition and the practice of medicine in general and interventional pain management in particular (8-16). Numerous developments, questions and issues have been reported in recent years with regard to multiple interventional techniques, including percutaneous adhesiolysis.

It has become an essential part of medicine to provide randomized comparative effectiveness or efficacy trials to prove the clinical, as well as cost effectiveness, of multiple treatments provided $(1,2)$.

\subsection{Introduction}

Treatment of chronic low back pain with or without lower extremity pain continues to be a challenge. Epidural steroids are commonly utilized in patients after the failure of conservative management $(5,9-29)$. The results of epidural steroid injections have been variable based on the pathophysiology, the route of administration, injected drugs, and utilization of fluoroscopy (5,9-29). In patients resistant to fluoroscopically directed epidural injections, percutaneous targeted delivery of injected drugs with or without adhesiolysis has been recommended (30-44). A number of studies have reported the effectiveness of percutaneous adhesiolysis in post laminectomy syndrome and spinal stenosis (3343). However, patients who are recalcitrant to epidural steroid injections without a history of post surgery syndrome or spinal stenosis have not been studied separately using targeted delivery of medication with or without percutaneous lumbar epidural adhesiolysis.

\subsection{Targeted Delivery of Steroids, Adhesioly- sis, and Hypertonic Saline Neurolysis}

Adhesiolysis of epidural scar tissue, followed by the injection of hypertonic saline, has been described by Racz and coworkers in multiple publications. The technique described by Racz and colleagues involved epidurography, adhesiolysis, and injection of hyaluronidase, bupivacaine, triamcinolone diacetate, and $10 \%$ sodium chloride solution on day one, followed by injections of bupivacaine and hypertonic sodium chloride solution on days 2 and 3 . Manchikanti and colleagues modified the Racz protocol from a 3-day procedure to a one-day procedure.

The goal of percutaneous lysis of epidural adhesions is to assure delivery of high concentrations of injected drugs to the target areas. Thus, percutaneous epidural lysis of adhesions is the first and most commonly used treatment to incorporate multiple therapeutic goals $(31,32)$.

A number of studies have demonstrated the efficacy of percutaneous adhesiolysis. The majority of the studies used a heterogeneous population, which also included a non-surgical population and a spinal stenosis population. Thus, it is very difficult to interpret the results specific to non-surgical and non-spinal stenosis patients with either disc herniation or degenerative disc disease.

Manchikanti et al (34) evaluated the role of adhesiolysis, specifically with a control group receiving epidural steroid injection only where the catheter was inserted without adhesiolysis, followed by an injection of epidural steroid and local anesthetic injection with so- 
dium chloride solution injection with a catheter in place in the sacral region (S2 or S3), and with Group II and Group III undergoing adhesiolysis. Also, Manchikanti et al (42) evaluated the effectiveness of adhesiolysis only in post lumbar surgery syndrome patients with publication of the preliminary results. These results showed $73 \%$ of patients responding positively in the intervention group. The protocol was similar to the one described above (34). Manchikanti et al (43) also evaluated the effectiveness of adhesiolysis in spinal stenosis. All 6 studies $(33,34,40-43)$ showed positive results for short-term and long-term improvement with adhesiolysis, either over the control group or with patients as their own controls.

\subsection{Pathophysiology}

Epidural fibrosis is a progressive disease. There are many possible etiologies of epidural fibrosis, including annular tear, hematoma, infection, surgical trauma, or intrathecal contrast media (45). LaRocca and Macnab (46) have demonstrated the invasion of fibrous connective tissue into the postoperative hematoma as a cause of epidural fibrosis. McCarron et al (47) investigated the irritative effect of material from the nucleus pulposus upon the dural sac, adjacent nerve roots, and nerve root sleeves independent of the influence of direct compression upon these structures. McCarron (48) further explored epidural fibrosis in an experimental model in adult mongrel dogs. He reported an inflammatory reaction in the spinal cord sections taken from dogs sacrificed after the initial injection of homogenized nucleus pulposus, whereas the spinal cord was grossly normal after the initial injection of normal saline.

Lumbosacral radicular syndrome is known by a range of terms in the literature, such as "sciatica," "radiculitis," "radiculopathy," "nerve root pain," and "nerve root entrapment" or "irritation" (49). Radicular pain is readily recognized in most cases in clinical practice in low back pain. It is generally defined as pain radiating to the leg, normally below the knee and into the foot and toes. The first to create widespread interest in the disc as a source of radicular pain in American literature were Mixter and Barr (50) with their 1934 hallmark description of the herniated nucleus pulposus. However, the pathophysiology of lumbar radicular pain is a subject of ongoing research and controversy with only a limited causative role for disc herniation and radiculitis, with non-specific or discogenic and facet joint pain assuming major roles (51-74). The pathophysiology of radicular pain assumes not only a mechanical component, but also multiple other factors including inflammation of the compressed nerve root, vascular compromise, and neurotoxicity $(47,74-85)$.

Kuslich et al (69) identified intervertebral discs, facet joints, ligaments, fascia, muscles, and nerve root dura as tissues capable of transmitting pain in the low back. The human intervertebral disc in the lumbar spine has been known to cause low back and lower extremity pain secondary to disc disruption, disc herniation, and nerve root compression $(49,50,68-95)$. Nerve root compression may be caused by disc herniation, spinal stenosis, and osteoarthritis. Chemical radiculitis and residual pain after surgical interventions, also known as post surgery syndrome, are also common factors in the causation of low back and lower extremity pain related to the disc (91-95).

\subsection{Rationale}

It has been reasoned that inflammation, edema, fibrosis, and venous congestion; mechanical pressure on posterior longitudinal ligaments, annulus fibrosus, and spinal nerve; reduced or absent nutrient delivery to the spinal nerve or nerve root; and central sensitization may be present in patients with radiculitis with disc herniation, stenosis, and epidural fibrosis. Hence, it has been postulated as reasonable to treat back pain with or without radiculopathy with the local application of anti-inflammatory medication agents (e.g., corticosteroids) aimed at reducing edema (e.g., hypertonic sodium chloride solution, corticosteroids), local anesthetics, and hyaluronidase to promote lysis $(32,33)$. Thus, percutaneous lysis of adhesions is indicated in patients with appropriate diagnostic evaluation and after the failure or ineffectiveness of conservative modalities of treatment have been proven.

The underlying mechanism of action of epidurally administered steroid and local anesthetic injections is still not well understood. It is believed that the achieved neural blockade alters or interrupts nociceptive input, reflex mechanism of the afferent fibers, self-sustaining activity of the neurons, and the pattern of central neuronal activities $(5,21,68,96,97)$. Further, corticosteroids have been shown to reduce inflammation by inhibiting either the synthesis or release of a number of pro-inflammatory mediators and by causing a reversible local anesthetic effect (97-105). In contrast, local anesthetics have been described to provide short- to long-term symptomatic relief by suppression of nociceptive discharge (106-108), the block of axonal transport $(109,110)$ of the sympathetic reflex arch 
(111), the block of sensitization (112), and anti-inflammatory effect (113). The long-lasting effect of local anesthetics in nerve blocks has been demonstrated in multiple studies (17-20,113-119). Sato et al (116) evaluated the prolonged analgesic effect of epidural bupivacaine in a rat model of neuropathic pain and concluded that repetitive administration of bupivacaine into the epidural space in rats exerts an analgesic effect, possibly by inducing a plastic change in nociceptive input. Further, Tachihara et al (120) showed in rats that nerve root infiltration prevented mechanical allodynia, however, no additional benefit from using corticosteroid was identified, suggesting that corticosteroid may be unnecessary for nerve root blocks.

\subsection{Complications}

The most common and worrisome complications of adhesiolysis in the lumbar spine are related to dural puncture, spinal cord compression, catheter shearing, infection, steroids, hypertonic saline, and hyaluronidase (121-138).

Spinal cord compression following rapid injections into the epidural space, which may cause large increases in intraspinal pressure with a risk of cerebral hemorrhage, visual disturbance, headache, and compromise of spinal cord blood flow, has been mentioned. However, the only complication reported following epidural injection has been vision loss; no such complications have been reported following adhesiolysis and hypertonic saline neurolysis.

Epidural infection following this procedure is a distinct possibility due to the procedure itself, as well as potential immunosuppression secondary to steroid injection.

The potential of spinal cord trauma is more likely with percutaneous adhesiolysis with hypertonic saline injection than with other epidural procedures including epidural injections, as the injection of adjuvant agents with preservatives may be unforgiving. Additional issues with transforaminal epidural adhesiolysis include intravascular penetration and neural trauma that may be higher than caudal or intralaminar. The incidence of vascular epidural injections documented by contrastenhanced fluoroscopic imaging and negative blood aspiration has varied from $5 \%$ to $11 \%$.

Neural trauma is a potential complication even though there are no such case reports either with caudal or transforaminal epidural adhesiolysis.

Other side effects are related to the administration of steroids, and are generally attributed to the chemistry or pharmacology of the steroids. The major theo- retical complications of corticosteroid administration include arachnoiditis, suppression of the pituitary-adrenal axis, hypocorticism, Cushing's syndrome, osteoporosis, avascular necrosis of bone, steroid myopathy, weight gain, fluid retention, and hyperglycemia. Other potential complications include hypertension, hypokalemia, epidural lipomatosis, retinal hemorrhage, increased intraocular pressure, subcapsular cataract formation, insomnia, mood swings, psychosis, facial flushing, headache, gastrointestinal disturbances, and menstrual disturbances. Manchikanti et al (138) evaluated the effect of neuraxial steroids on weight and bone mass density prospectively. The results of serial determination of weight and bone mass density showed no significant change at any interval or at the end of one year. They concluded that low-dose administration of neuraxial steroids is safe in patients suffering with chronic pain who have failed to respond to conservative modalities of treatments with a favorable risk-benefit ratio, without any deleterious effects either on body weight or bone mass density.

\subsection{Investigational Methodology}

\subsection{Site and Location}

The study will be conducted in an interventional pain management practice and a specialty referral center in a private practice setting in the United States. The study will be performed based on Consolidated Standards of Reporting Trials (CONSORT) guidelines and an extension of the CONSORT statement reporting non-inferiority and equivalence in randomized trials $(139,140)$.

\subsection{IRB Approval of Study Protocol}

The study protocol has been approved by the Institutional Review Board (IRB) and has been registered in the U.S. Clinical Trial Registry with an assigned number of NCT01053273.

\subsection{Informed Consent}

All patients will be provided with the IRB-approved protocol and informed consent which will describe in detail all aspects of the study and withdrawal process.

Patients considered suitable by the investigator for participation in this clinical investigation will be given a verbal explanation of the nature of their clinical condition and this investigation and supplied with written informed consent. Each patient will be allowed sufficient time to decide whether they wish to participate in this investigation. The investigator or another member 
of the investigative team will address any questions regarding this investigation appropriately.

Patients will be instructed that they are free to obtain further information from the investigator at any time, that they are free to withdraw their consent, and to discontinue their participation in the study at any time without prejudice. If the patient is willing to participate in this investigation, written informed consent will be obtained. Written informed consent from the subject must be obtained before any of the screening procedures are performed. In addition, the consent must be written in a language in which the patient is literate.

\subsection{Participants}

The study is designed to assign 120 patients into 2 groups: Group I will receive caudal epidural injections with catheterization up to S3 with local anesthetic, steroids, and $0.9 \%$ sodium chloride solution; Group II will receive percutaneous adhesiolysis with targeted delivery of lidocaine, $10 \%$ hypertonic sodium chloride solution, and non-particulate betamethasone.

\subsubsection{Participant Flow}

Participant flow will be described utilizing schematic presentation of patient flow with a flow diagram as recommended by CONSORT $(139,140)$.

\subsection{Interventions}

The summary of steps of the procedure are illustrated in Table 1.

\subsubsection{Description of Interventions}

All procedures will be performed in a sterile operating room under sterile conditions utilizing fluoros- copy and a specially designed RK needle and a Racz ${ }^{\circledR}$ catheter 19 gauge Brevi-STF.

\subsubsection{Procedure}

The procedure will include appropriate preparation with intervenous access, antibiotic administration, and appropriate sedation.

An RK needle will be introduced into the sacral epidural space under intermittent fluoroscopy. Once the needle placement is confirmed to be in the epidural space, a lumbar epidurogram will be carried out, utilizing approximately $5 \mathrm{~mL}$ of contrast (Omnipaque $® 240$ ). Identification of the filling defects will be carried out by examining the contrast flow into the nerve roots. Intravascular or subarachnoid placement of the needle or contrast will be avoided; if such malpositioning occurs, the needle will be repositioned.

In Group I, after appropriate determination of epidurography, a Racz catheter will be passed through the RK needle up to S3 and additional Omnipaque 240, 3 $\mathrm{mL}$, will be injected. Following this, $5 \mathrm{~mL}$ of $2 \%$ preservative-free Xylocaine will be injected into the epidural space through the catheter.

In Group II, after identification of the filling defects, the Racz catheter will be advanced through the RK needle to the area of the filling defect or the site of pathology as determined by magnetic resonance imaging (MRI), computed tomography (CT), or symptomatology.

Adhesiolysis will be carried out and the final positioning will be achieved in the epidural space laterally and ventrally. After satisfactory positioning, at least 3 $\mathrm{mL}$ of contrast will be injected. If there is no subarachnoid, intravascular, or other extra epidural filling and

Table 1. Summary of steps and procedural considerations.

\begin{tabular}{|l|l||}
\hline \multicolumn{1}{|c|}{ GROUP I (Control Group) } & \multicolumn{1}{c|}{ GROUP II (Intervention Group) } \\
\hline 1. Preparation & 1. Preparation \\
\hline 2. Epidurography & 2. Epidurography \\
\hline 3. Introduction of catheter up to S3 or S2 & 3. Introduction of catheter to level of defect \\
\hline 4. No adhesiolysis & 4. Adhesiolysis and/or targeted catheter positioning \\
\hline 5. Repeat epidurography & 5. Epidurography with confirmation of ventral and lateral filling \\
\hline 6. Injection of $5 \mathrm{~mL}$ of $2 \%$ lidocaine & 6. Injection of $5 \mathrm{~mL}$ of $2 \%$ lidocaine \\
\hline 7. Transfer to recovery room & 7. Transfer to recovery room \\
\hline 8. Injection of $6 \mathrm{~mL}$ of normal saline & 8. Injection of $6 \mathrm{~mL}$ of $10 \%$ sodium chloride solution \\
\hline 9. Injection of $6 \mathrm{mg}$ of non-particulate betamethasone & 9. Injection of $6 \mathrm{mg}$ of non-particulate betamethasone \\
\hline 10. Injection of $1 \mathrm{~mL}$ of normal saline and removal of catheter & 10. Injection of $1 \mathrm{~mL}$ of normal saline and removal of catheter \\
\hline
\end{tabular}


satisfactory filling is obtained with epidural and targeted nerve root filling, $5 \mathrm{~mL}$ of $2 \%$ preservative-free Xylocaine will be injected.

\subsubsection{Recovery Room}

After 10 to 15 minutes of monitoring, the injection of sodium chloride solution $(0.9 \%$ in Group I or $10 \%$ in Group II) will be carried out by repeat injection in doses of 2 to $3 \mathrm{~mL}$, followed by injection of $6 \mathrm{mg}$ of non-particulate Betamethasone and $1 \mathrm{~mL}$ of sodium chloride solution and then removal of the catheter.

The patient will be ambulated if all parameters are satisfactory. Intravenous access will be removed and the patient will be discharged home with appropriate instructions.

Repeat percutaneous adhesiolysis injections will be provided based on the response to the prior injections evaluated by improvement in physical and functional status followed by subsequent increased levels of pain being reported and deteriorating relief below $50 \%$ and with deterioration in functional status.

\subsubsection{Devices}

In order to perform the percutaneous adhesiolysis procedure, RK \#15-gauge coude needle and Racz catheter \#19 gauge XL STF and other items are required. These items are manufactured by:

Epimed Inc.

3100 Premiere Drive, Suite 232

Irving TX 75063

Telephone: 800-727-1201

\subsubsection{Additional Interventions}

All the patients will undergo the treatments as assigned. A patient will be unblinded on request or if an emergency situation exists. If a patient requires additional procedures, they will be provided based on the response to the previous injections, either after unblinding or without unblinding. If the patient chooses not to be unblinded, the prior treatment will be repeated as assigned. Patients who are non-responsive, but continue with conservative management, will be followed without further study procedures with medical management, unless they request unblinding. In addition, all patients who are unblinded at any time and those who are lost to follow-up at one year will be considered withdrawn.

\subsubsection{Co-Interventions}

It is expected that most patients will be receiving opioid and non-opioid analgesics, as well as adjuvant analgesics; some will be involved in a therapeutic exercise program. If patients improve significantly and the medical necessity for these drugs is lacking, medications will be stopped or dosages will be decreased. In addition, dosages will also be increased based on medical necessity. All patients will continue previously directed exercise programs, as well as their work. Thus, no specific physical therapy, occupational therapy, bracing, or other interventions are offered other than the study intervention.

\subsection{Pre-Enrollment Evaluation}

The pre-enrollment evaluation will include collection of demographic data, medical and surgical history listing co-existing disease(s), radiologic investigations, physical examination, pain rating scores using the numeric rating scale (NRS), work status, opioid intake, and functional status assessment by the Oswestry Disability Index (ODI).

\subsubsection{Inclusion Criteria}

Patients with a history of chronic function-limiting low back pain with or without lower extremity pain of at least 6 months duration; and patients who are competent to understand the study protocol and provide voluntary, written informed consent and participate in outcome measurements.

Inclusion criteria will also include no evidence of facet joint pain and failure to improve substantially with conservative management including but not limited to physical therapy, chiropractic manipulation, exercises, drug therapy, bedrest, and fluoroscopically directed caudal or transforaminal epidural injections.

Exclusion criteria will include post surgery syndrome, central spinal stenosis, and facet joints as sole pain generators, unstable or heavy opioid use $(400 \mathrm{mg}$ of morphine equivalents daily), uncontrolled psychiatric disorders, uncontrolled medical illness, any conditions that could interfere with the interpretation of the outcome assessments, pregnant or lactating women, and patients with a history or potential for adverse reaction(s) to local anesthetic, steroids, or hypertonic sodium chloride solution.

\subsubsection{Subject Eligibility and Identification}

Once signed informed consent has been obtained from the patient, the eligibility checklists contained in the case report form (CRF) will be completed. 
Where a patient fails to fulfill any element of the inclusion and exclusion criteria, the failure will be documented in the patient source notes. The investigator will retain the signed consent form and completed eligibility. These patients will not be enrolled into this clinical investigation.

\subsubsection{Contraindications}

Contraindications include, but are not limited to, coagulopathy, pregnancy, renal insufficiency, chronic liver dysfunction, history of adverse reaction to local anesthetic or anti-inflammatory drugs, history of gastrointestinal bleeding or ulcers, urinary sphincter dysfunction, progressive neurological deficit, infection, increased intracranial pressure, pseudotumor cerebri, intracranial tumors, unstable angina, severe chronic obstructive pulmonary disease, inability to achieve appropriate positioning, and inability to understand informed consent and protocol. The procedure should never be performed under general anesthesia. Other minor or related contraindications include generalized symptomatology as well as active untreated or resistant psychiatric disorders affecting physical condition, and visual deficiencies.

\subsection{Objectives}

The study is designed to evaluate the effectiveness of percutaneous epidural adhesiolysis in managing chronic low back and/or lower extremity pain in patients without post lumbar surgery syndrome or spinal stenosis and compare it with fluoroscopically directed caudal epidural steroid injections.

\subsection{Outcomes}

Multiple outcome measures will be utilized including the NRS $(0-10$ scale), the ODI on a $0-50$ scale, employment status, and opioid intake in terms of daily intake of morphine equivalents, with assessment at $3,6,12,18$, and 24 months post treatment. The value and validity of the NRS and ODI have been reported (141-145). Thresholds for the minimum clinically important difference for the ODI varied from a 4 to 15 point change from a total score of 50 . Significant pain relief is described as $50 \%$ or more reduction in the NRS from baseline, whereas significant improvement in function is described as at least a $40 \%$ reduction in the ODI (26-29,42,43,117-119).

Based on the dosage frequency and schedule of the drug, the opioid intake will be converted into morphine equivalents (146).

Employment and work status will be determined based on employability at the time of enrollment rather than including all patients in the study as employable. Employment and work status will be classified into multiple categories such as employable, housewife with no desire to work outside the home, retired, or over the age 65. Patients who are unemployed due to pain or employed but on sick leave or laid off will be considered as employable.

\subsection{Data Management and Analysis}

\subsubsection{Sample Size}

Sample size was calculated based on reduction of NRS. A $25 \%$ clinical difference change of 1.15 (d) was set from a previous study (34). With standard deviation $(\sigma)$ of the NRS of $2.3, \delta=d / \sigma, \delta=0.50$, to achieve an alpha of 0.05 and beta of 0.20 with $80 \%$ power (147), it will require 60 patients in each group of the trial. One hundred patients in each group would provide 95\% power (i.e., alpha and beta of 0.05).

Previous studies of interventional techniques have confirmed that 50 to 60 patients is acceptable $(26-29,42,43,117-119,148)$.

\subsubsection{Statistical Methods}

Statistical analysis will include chi-squared statistic, Fisher's exact test, t-test, and paired t-test. Results will be considered statistically significant if the $P$ value is less than 0.05 .

Chi-squared statistic will be used to test the differences in proportions. Fisher's exact test will be used wherever the expected value is less than 5; a paired ttest will be used to compare the pre- and post-treatment results of average pain scores and ODI measurements at baseline versus 3, 6, 12, 18, and 24 months. For comparison of mean scores between groups, a t-test will be performed.

\subsubsection{Intent-to-Treat-Analysis}

An intent-to-treat-analysis will be performed. Either the last follow-up data or initial data will be utilized in the patients who drop out of the study and no other data is available.

\subsection{Randomization}

A total of 120 patients with 60 patients randomly assigned into 2 groups.

\subsubsection{Sequence Generation}

Randomization will be performed by computer 
generated random allocations sequence by simple randomization.

\subsubsection{Allocation Concealment}

The operating room nurse assisting with the procedure will randomize the patients and prepare the drugs appropriately.

\subsubsection{Implementation}

Participants will be invited to enroll in the study if they meet inclusion criteria. One of 3 nurses assigned as coordinators of the study will enroll the participants and assign participants to their respective groups.

\subsubsection{Blinding (Masking)}

Participants and those administering the interventions will be blinded to the group assignment. The blinding will be assured by mixing the patients with other patients receiving routine treatment and not informing the physician performing the procedure of the inclusion of the patients in the study.

\subsection{Safety Assessments}

\subsection{Adverse Event Occurrence}

At each follow-up assessment $(3,6,12,18$, and 24 months post-treatment), details of any adverse event or adverse device effect reported by the subject will be recorded in the CRF. Details to be recorded include the nature, onset, duration, severity, and relationship to the invasive procedure and outcome of the event.

The occurrence of adverse events (including new illnesses, worsening symptoms of coexisting diseases, or additional symptoms) will be identified by spontaneous reports from the subject or by clinical/radiological assessment.

\subsection{Adverse Event Reporting}

According to the FDA's Clinical Investigation of Medical Devices for Human Subjects, an adverse event is defined as "any undesirable clinical occurrence in a subject whether it is considered device related or not." In addition, an adverse device effect or undesirable side effect, is defined as "a device related adverse event."

A record of all adverse events, as well as details of the nature, onset, duration, severity, and relationship to the device, will be recorded on the relevant section(s) of the subject's CRF. The subject will be questioned about any adverse event(s) at each subsequent follow-up assessment visit.
An adverse event or an adverse device effect may be mild, moderate, or severe, and is usually unexpected. A serious adverse event or adverse device effect is defined as any experience that:

1) Is fatal or life-threatening;

2) Is permanently incapacitating or disabling;

3) Requires in-patient hospitalization because of a potential disability, danger to life, or an intervention has been necessitated;

4) Malignancy results.

All serious adverse events or serious adverse device effects, which occur during this investigation, must be reported immediately by telephone or facsimile to the IRB.

The investigator should institute appropriate therapeutic and follow-up measures in accordance with good medical practice but should notify the study monitor of such actions and record them in the subject's CRF.

\subsection{Results}

\subsection{Participant Flow}

An illustration of the participant flow will be as shown in Fig. 1.

\subsection{Recruitment}

The recruitment period is from February 1, 2010, to January 31, 2012.

\subsection{Baseline Data}

Baseline demographic and clinical characteristics of each group will be illustrated as shown in Table 2 . Significant differences will be assessed between the groups.

\subsection{Analysis of Data}

\subsubsection{Numbers Analyzed}

A schematic illustration of patient flow will be provided in Fig. 1. The duration of the study is proposed from February 1, 2010, to January 31, 2012, with selection of 120 patients with 60 patients in each group.

\subsection{Outcomes and Estimation}

\subsubsection{Pain Relief}

Table 3 will illustrate the NRS scores and changes at $3,6,12,18$, and 24 months in all groups, with significant differences assessed between the groups at baseline and at all follow-up periods. 


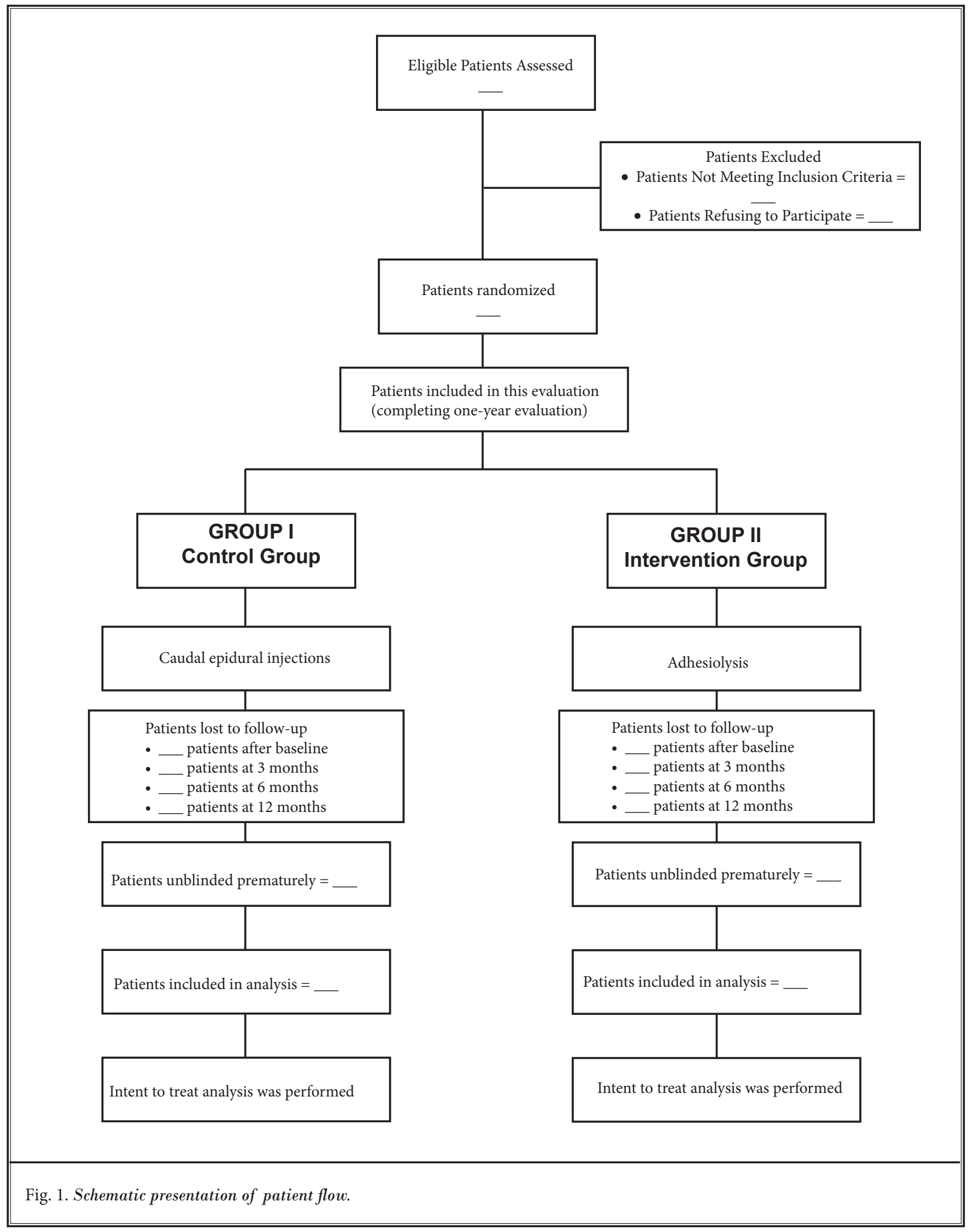


Table 2. Demographic characteristics.

\begin{tabular}{|c|c|c|c|c|}
\hline & & $\begin{array}{c}\text { Group I } \\
(\mathbf{N}=60)\end{array}$ & $\begin{array}{l}\text { Group II } \\
(\mathbf{N}=60)\end{array}$ & $P$ value \\
\hline \multirow[t]{2}{*}{ Gender } & Male & & & \\
\hline & Female & & & \\
\hline Age & Mean \pm SD & & & \\
\hline Height (inches) & Mean \pm SD & & & \\
\hline Weight (lbs.) & Mean \pm SD & & & \\
\hline Duration of pain (months) & Mean \pm SD & & & \\
\hline \multirow[t]{2}{*}{ Mode of onset of pain } & Non-traumatic & & & \\
\hline & Traumatic & & & \\
\hline \multirow[t]{5}{*}{ Leg pain Distribution } & Bilateral & & & \\
\hline & Left only & & & \\
\hline & Left worse & & & \\
\hline & Right only & & & \\
\hline & Right worse & & & \\
\hline
\end{tabular}

Table 3. Pain relief characteristics.

\begin{tabular}{|l|c|c|c|c|}
\hline \multirow{3}{*}{ Average pain scores (mean \pm SD) } & & $\begin{array}{c}\text { Group I } \\
(\mathbf{N}=\mathbf{6 0})\end{array}$ & $\begin{array}{c}\text { Group II } \\
(\mathbf{N}=\mathbf{6 0})\end{array}$ & P value \\
\cline { 2 - 5 } & Baseline & & & \\
\cline { 2 - 5 } & 3 months & & & \\
\cline { 2 - 5 } & 6 months & & & \\
\cline { 2 - 5 } & 12 months & & & \\
\cline { 2 - 5 } & 18 months & & & \\
\hline
\end{tabular}

\# indicates significant difference with baseline values

Table 4. Functional assessment evaluated by Oswestry Disability Index.

\begin{tabular}{|l|c|c|c|c||}
\hline \hline & & $\begin{array}{c}\text { Group I } \\
(\mathbf{N}=\mathbf{6 0})\end{array}$ & $\begin{array}{c}\text { Group II } \\
(\mathbf{N}=\mathbf{6 0})\end{array}$ & P value \\
\hline $\begin{array}{l}\text { Average Oswestry Disability Index } \\
(\text { Mean } \pm \text { SD) }\end{array}$ & Baseline & & & \\
\cline { 2 - 5 } & 3 months & & & \\
\cline { 2 - 5 } & 6 months & & & \\
\cline { 2 - 5 } & 12 months & & & \\
\cline { 2 - 5 } & & & & \\
\hline
\end{tabular}

\# indicates significant difference with baseline values

In addition, the proportion of patients with significant pain relief $(\geq 50 \%)$ will be illustrated in a figure format.

\subsection{Functional Assessment}

Functional assessment results will be assessed by the ODI and will be illustrated as shown in Table 4 and in a figure format. 
Table 5. Employment characteristics.

\begin{tabular}{|l|l|l|l|l||}
\hline \multirow{2}{*}{ Employment status } & \multicolumn{1}{c|}{ Group I } & \multicolumn{2}{c|}{ Group II } \\
\cline { 2 - 5 } & \multicolumn{1}{c|}{ Baseline } & \multicolumn{1}{c|}{ 12 months } & Baseline & \\
\hline Employed part-time & & & & \\
\hline Employed full-time & & & & \\
\hline Unemployed & & & & \\
\hline Total employed & & & & \\
\hline Eligible for employment & & & & \\
\hline Housewife & & & & \\
\hline Disabled & & & & \\
\hline Over 65 year of age & & 60 & 60 & 60 \\
\hline Total number of patients & 60 & & & \\
\hline
\end{tabular}

\subsection{Employment Characteristics}

Table 5 demonstrates the characteristics of employment to be evaluated in both groups.

\subsection{Opioid Intake}

Table 6 illustrates the methodology to be utilized for opioid intake between both groups and at various follow-up periods and statistical analysis.

\subsection{Therapeutic Procedural Characteristics}

Therapeutic procedural characteristics with average pain relief per procedure and average overall relief per year and differences between the groups will be
Table 6. Daily opioid (morphine equivalents).

\begin{tabular}{|l|l|l|l|}
\hline & Group I & Group II & P value \\
\hline Baseline & & & \\
\hline 3 months & & & \\
\hline 6 months & & & \\
\hline 12 months & & & \\
\hline
\end{tabular}

\# indicates significant difference $(P<0.01)$ with baseline values

Table 7. Illustration of procedural characteristics with procedural frequency, average relief per procedure, and average total relief in weeks over a period of one-year.

\begin{tabular}{|c|c|c|c|c|}
\hline \multirow[b]{2}{*}{ Procedure number } & \multicolumn{2}{|c|}{ Back Pain } & \multicolumn{2}{|c|}{ Leg Pain } \\
\hline & $\begin{array}{c}\text { Group I } \\
(\mathbf{N}=\mathbf{6 0})\end{array}$ & $\begin{array}{l}\text { Group II } \\
(\mathbf{N}=60)\end{array}$ & $\begin{array}{c}\text { Group I } \\
(\mathbf{N}=\mathbf{6 0})\end{array}$ & $\begin{array}{l}\text { Group II } \\
(\mathrm{N}=60)\end{array}$ \\
\hline \multicolumn{5}{|l|}{ 1st injection relief } \\
\hline \multicolumn{5}{|l|}{ 2nd injection relief } \\
\hline \multicolumn{5}{|l|}{ 3rd injection relief } \\
\hline \multicolumn{5}{|l|}{ 4th injection relief } \\
\hline \multicolumn{5}{|l|}{ Number of injections per year } \\
\hline \multicolumn{5}{|l|}{ Total relief per year (weeks) } \\
\hline Average relief per procedure & & & & \\
\hline
\end{tabular}

* indicates significant difference between groups $(P<0.05)$ 
illustrated as shown in Table 7.

\subsection{Adverse Events}

Adverse events will be reported.

\subsection{Conclusion}

This article describes the protocol for evaluation of the comparative effectiveness of percutaneous adhesiolysis and caudal epidural steroid injections in low back and/or lower extremity pain without post surgery syndrome or spinal stenosis, in an interventional pain management center and a referral center in the United
States. The protocol utilizes CONSORT guidelines and all the prerequisites for randomized equivalence trials and comparative effectiveness evaluation. Further, the protocol utilizes approved methodology with appropriate consent, and the Health Insurance Portability and Accountability Act (HIPAA) and ethical regulations. This study is the first of its nature in the United States to evaluate the role of targeted delivery of drugs in recalcitrant low back pain with or without adhesiolysis.

\section{Acknowledgments}

The authors wish to thank Sekar Edem for his assis-

\section{References}

1. Manchikanti L, Boswell MV, Giordano J. Evidence-based interventional pain management: Principles, problems, potential and applications. Pain Physician 2007; 10:329-356.

2. Manchikanti L. Evidence-based medicine, systematic reviews, and guidelines in interventional pain management: Part 1: Introduction and general considerations. Pain Physician 2008; 11:161-186.

3. Manchikanti L, Falco FJE, Boswell MV, Hirsch JA. Facts, fallacies, and politics of comparative effectiveness research: Part I. Basic considerations. Pain Physician 2010; 13:E23-E54.

4. Manchikanti L, Falco FJE, Boswell MV, Hirsch JA. Facts, fallacies, and politics of comparative effectiveness research: Part 2 - Implications for interventional pain management. Pain Physician 2010; 13:E55-E79.

5. Manchikanti L, Boswell MV, Singh V, Benyamin RM, Fellows B, Abdi S, Buenaventura RM, Conn A, Datta S, Derby R, Falco FJE, Erhart S, Diwan S, Hayek SM, Helm S, Parr AT, Schultz DM, Smith HS, Wolfer LR, Hirsch JA. Comprehensive evidence-based guidelines for interventional techniques in the management of chronic spinal pain. Pain Physician 2009: 12:699-802.

6. Manchikanti L, Singh V, Helm S, Schultz DM, Datta S, Hirsch J. An introduction to an evidence-based approach to interventional techniques in the management of chronic spinal pain. Pain Physician 2009; 12:E1-E33.

7. Eden J, Wheatley B, McNeil B, Sox H. Knowing What Works in Health Care: A Roadmap for the Nation. National Academies Press, Washington, DC,
2008.

8. Manchikanti L. Health care reform in the United States: Radical surgery needed now more than ever. Pain Physician 2008; 11:13-42.

9. Manchikanti L, Singh V, Pampati V, Smith HS, Hirsch J. Analysis of growth of interventional techniques in manag. ing chronic pain in the medicare population: A 10-year evaluation from 1997 to 2006. Pain Physician 2009; 12:9-34.

10. Manchikanti L. Medicare in interventional pain management: A critical analysis. Pain Physician 2006; 9:171-198.

11. Manchikanti L, Boswell MV. Interventional techniques in ambulatory surgical centers: A look at the new payment system. Pain Physician 2007; 10:627650.

12. Manchikanti L, Giordano J. Physician payment 2008 for interventionalists: Current state of health care policy. Pain Physician 2007; 10:607-626.

13. Friedly J, Chan L, Deyo R. Increases in lumbosacral injections in the Medicare population: 1994 to 2001. Spine (Phila $\mathrm{Pa}$ 1976) 2007; 32:1754-1760.

14. US Department of Health and Human Services. Office of Inspector General (OIG). Medicare Payments for Facet Joint Injection Services (OEI-05-0700200). September 2008. www.oig. hhs.gov/oei/reports/oei-05-07-00200. pdf Accessed Feb. 22, 2010

15. Manchikanti L, Hirsch JA. Issues in health care: Interventional pain management at the crossroads. Health policy update. Pain Physician 2007; 10:261284.

16. Specialty Utilization data files from CMS: www.cms.hhs.gov Accessed Feb. 22, 2010
17. Conn A, Buenaventura R, Datta S, Abdi $S$, Diwan S. Systematic review of caudal epidural injections in the management of chronic low back pain. Pain Physician 2009; 12:109-135.

18. Parr AT, Diwan S, Abdi S. Lumbar interlaminar epidural injections in managing chronic low back and lower extremity pain: A systematic review. Pain Physician 2009; 12:163-188.

19. Buenaventura RM, Datta S, Abdi S, Smith HS. Systematic review of therapeutic lumbar transforaminal epidural steroid injections. Pain Physician 2009; 12:233-251.

20. Benyamin RM, Singh V, Parr AT, Conn A, Diwan S, Abdi S. Systematic review of the effectiveness of cervical epidurals in the management of chronic neck pain. Pain Physician 2009; 12:137-157.

21. Manchikanti L, Boswell MV, Datta S, Fellows B, Abdi S, Singh V, Benyamin RM, Falco FJE, Helm S, Hayek S, Smith HS. Comprehensive review of therapeutic interventions in managing chronic spinal pain. Pain Physician 2009; 12:E123E198.

22. Manchikanti L, Helm S, Singh V, Benyamin RM, Datta S, Hayek S, Fellows B, Boswell MV. An algorithmic approach for clinical management of chronic spinal pain. Pain Physician 2009; 12: E225E264.

23. Chou R, Loeser JD, Owens DK, Rosenquist RW, Atlas SJ, Baisden J, Carragee EJ, Grabois M, Murphy DR, Resnick DK, Stanos SP, Shaffer WO, Wall EM. American Pain Society Low Back Pain Guideline Panel. Interventional therapies, surgery, and interdisciplinary rehabilitation for low back pain: An evidencebased clinical practice guideline from 
the American Pain Society. Spine (Phila $\mathrm{Pa}$ 1976) 2009; 34:1066-1077.

24. Chou R, Atlas SJ, Stanos SP, Rosenquist RW. Nonsurgical interventional therapies for low back pain: A review of the evidence for an American Pain Society clinical practice guideline. Spine (Phila Pa 1976) 2009; 34:1078-1093.

25. Armon C, Argoff CE, Samuels J, Backonja M. Assessment: Use of epidural steroid injections to treat radicular lumbosacral pain: Report of the Therapeutics and Technology Assessment Subcommittee of the American Academy of Neurology. Neurology 2007; 68:723729.

26. Manchikanti L, Singh V, Cash KA, Pampati V, Damron KS, Boswell MV. Preliminary results of randomized, equivalence trial of fluoroscopic caudal epidural injections in managing chronic low back pain: Part 2. Disc herniation and radiculitis. Pain Physician 2008; 11:801-815.

27. Manchikanti L, Cash KA, McManus CD, Pampati V, Smith HS. Preliminary results of randomized, equivalence trial of fluoroscopic caudal epidural injections in managing chronic low back pain: Part 1. Discogenic pain without disc herniation or radiculitis. Pain Physician 2008; 11:785-800.

28. Manchikanti L, Singh V, Cash KA, Pampati V, Datta S. Preliminary results of randomized, equivalence trial of fluoroscopic caudal epidural injections in managing chronic low back pain: Part 3. Post surgery syndrome. Pain Physician 2008; 11:817-831.

29. Manchikanti L, Cash KA, McManus CD, Pampati V, Abdi S. Preliminary results of randomized, equivalence trial of fluoroscopic caudal epidural injections in managing chronic low back pain: Part 4. Spinal stenosis. Pain Physician 2008; 11:833-848.

30. Epter RS, Helm S, Hayek SM, Benyamin RM, Smith HS, Abdi S. Systematic review of percutaneous adhesiolysis and management of chronic low back pain in post lumbar surgery syndrome. Pain Physician 2009; 12:361-378.

31. Manchikanti L, Boswell MV, Rivera JJ, Pampati V, Damron KS, McManus CD, Brandon DE, Wilson SR. A randomized, controlled trial of spinal endoscopic adhesiolysis in chronic refractory low back and lower extremity pain. $B M C$ Anesthesiol 2005; 5:10.

32. Manchikanti L, Bakhit CE. Percutane- ous lysis of epidural adhesions. Pain Physician 2000; 3:46-64.

33. Heavner JE, Racz GB, Raj P. Percutaneous epidural neuroplasty. Prospective evaluation of $0.9 \% \mathrm{NaCl}$ versus $10 \%$ $\mathrm{NaCl}$ with or without hyaluronidase. Reg Anesth Pain Med 1999; 24:202207.

34. Manchikanti L, Rivera JJ, Pampati V, Damron KS, McManus CD, Brandon DE, Wilson SR. One day lumbar epidural adhesiolysis and hypertonic saline neurolysis in treatment of chronic low back pain: A randomized, double-blind trial. Pain Physician 2004; 7:177-186.

35. Manchikanti L, Pakanati R, Bakhit CE, Pampati V. Role of adhesiolysis and hypertonic saline neurolysis in management of low back pain. Evaluation of modification of Racz protocol. Pain Digest 1999; 9:91-96.

36. Manchikanti L, Pampati V, Bakhit CE, Pakanati RR. Non-endoscopic and endoscopic adhesiolysis in post lumbar laminectomy syndrome. A one-year outcome study and cost effective analysis. Pain Physician 1999; 2:52-58.

37. Manchikanti L, Pampati V, Fellows B, Rivera JJ, Beyer CD, Damron KS. Role of one day epidural adhesiolysis in management of chronic low back pain: A randomized clinical trial. Pain Physician 2001; 4:153-166.

38. Manchikanti L, Pampati V, Rivera JJ, Fellows B, Beyer CD, Damron KS, Cash KA. Effectiveness of percutaneous adhesiolysis and hypertonic saline neurolysis in refractory spinal stenosis. Pain Physician 2001; 4:366-373.

39. Veihelmann A, Devens C, Trouiller H, Birkenmaier C, Gerdesmeyer L, Refior HJ. Epidural neuroplasty versus physiotherapy to relieve pain in patients with sciatica: A prospective randomized blinded clinical trial. J Orthop Science 2006; 11:365-369.

40. Gerdesmeyer L, Rechl H, Wagenpfeil S, Ulmer M, Lampe R, Wagner K. Minimally invasive epidural neurolysis in chronic radiculopathy. A prospective controlled study to prove effectiveness. Der Orhopade 2003; 32:869-876.

41. Gerdesmeyer L, Lampe R, Veihelmann A, Burgkart R, Gobel M, Gollwitzer H, Wagner K. Chronic radiculopathy. Use of minimally invasive percutaneous epidural neurolysis according to Racz. Der Schmerz 2005; 19:285-295.

42. Manchikanti L, Singh V, Cash KA, Pam- pati V, Datta S. A comparative effectiveness evaluation of percutaneous adhesiolysis and epidural steroid injections in managing lumbar post surgery syndrome: $A$ randomized, equivalence controlled trial. Pain Physician 2009; 12:E355-E368.

43. Manchikanti L, Cash KA, McManus CD, Pampati V, Singh V, Benyamin R. The preliminary results of a comparative effectiveness evaluation of adhesiolysis and caudal epidural injections in managing chronic low back pain secondary to spinal stenosis: A randomized, equivalence controlled trial. Pain Physician 2009; 12:E341-E354.

44. Hayek SM, Helm S, Benyamin RM, Singh V, Bryce DA, Smith HS. Effectiveness of spinal endoscopic adhesiolysis in post lumbar surgery syndrome: A systematic review. Pain Physician 2009; 12:419-435.

45. Racz GB, Heavner JE, Singleton W, Caroline $M$. Hypertonic saline and corticosteroid injected epidurally for pain control. In: Raj P (ed). Techniques of Neurolysis. Klumer Academic Publishers, Boston, 1989, pp 73-86.

46. LaRocca H, Macnab I. The laminectomy membrane: Studies in its evolution, characteristics, effects and prophylaxis in dogs. J Bone Joint Surg 1974; 56B:545-550.

47. McCarron RF, Wimpee MW, Hudkins PG, Laros GS. The inflammatory effects of nucleus pulposus: A possible element in the pathogenesis of low back pain. Spine (Phila Pa 1976) 1987; 12:760764.

48. McCarron RF. Epidural fibrosis: Experimental model and therapeutic alternatives. In: Racz GB (ed). Techniques of Neurolysis. Kluwer Academic Publishers, Boston, 1989, pp 87-94.

49. Konstantinou K, Dunn KM. Sciatica: Review of epidemiological studies and prevalence estimates. Spine (Phila Pa 1976) 2008; 33:2464-2472.

50. Mixter WJ, Barr JS. Rupture of the intervertebral disc with involvement of the spinal canal. N Eng / Med 1934; 211:210-215.

51. Atluri S, Datta S, Falco FJE, Lee M. Systematic review of diagnostic utility and therapeutic effectiveness of thoracic facet joint interventions. Pain Physician 2008; 11:611-629.

52. Falco FJE, Erhart S, Wargo BW, Bryce DA, Atluri S, Datta S, Hayek SM. Systematic review of diagnostic utility and 
therapeutic effectiveness of cervical facet joint interventions. Pain Physician 2009; 12:323-344.

53. Datta S, Lee M, Falco FJE, Bryce DA, Hayek SM. Systematic assessment of diagnostic accuracy and therapeutic utility of lumbar facet joint interventions. Pain Physician 2009; 12:437460.

54. Wolfer L, Derby R, Lee JE, Lee SH. Systematic review of lumbar provocation discography in asymptomatic subjects with a meta-analysis of false-positive rates. Pain Physician 2008; 11:513538.

55. Manchikanti L, Dunbar EE, Wargo BW, Shah RV, Derby R, Cohen SP. Systematic review of cervical discography as a diagnostic test for chronic spinal pain. Pain Physician 2009; 12:305-321.

56. Singh V, Manchikanti L, Shah RV, Dunbar EE, Glaser SE. Systematic review of thoracic discography as a diagnostic test for chronic spinal pain. Pain Physician 2008; 11:631-642.

57. Manchikanti L, Glaser S, Wolfer L, Derby $R$, Cohen SP. Systematic review of lumbar discography as a diagnostic test for chronic low back pain. Pain Physician 2009; 12:541-559.

58. Helm S, Hayek S, Benyamin RM, Manchikanti L. Systematic review of the effectiveness of thermal annular procedures in treating discogenic low back pain. Pain Physician 2009; 12:207-232.

59. Frey ME, Manchikanti L, Benyamin RM, Schultz DM, Smith HS, Cohen SP. Spinal cord stimulation for patients with failed back surgery syndrome: A systematic review. Pain Physician 2009; 12:379-397.

6o. Patel VB, Manchikanti L, Singh V, Schultz DM, Hayek SM, Smith HS. Systematic review of intrathecal infusion systems for long-term management of chronic non-cancer pain. Pain Physician 2009; 12:345-360.

61. Rupert MP, Lee M, Manchikanti L, Dat ta S, Cohen SP. Evaluation of sacroiliac joint interventions: A systematic appraisal of the literature. Pain Physician 2009; 12:399-418.

62. Hirsch JA, Singh V, Falco FJE, Benyamin RM, Manchikanti L. Automated percutaneous lumbar discectomy for the contained herniated lumbar disc: A systematic assessment of evidence. Pain Physician 2009; 12:601-620.

63. Singh V, Manchikanti L, Benyamin RM,
Helm S, Hirsch JA. Percutaneous lumbar laser disc decompression: A systematic review of current evidence. Pain Physician 2009; 12:573-588.

64. Singh V, Benyamin RM, Datta S, Falco FJE, Helm S, Manchikanti L. Systematic review of percutaneous lumbar mechanical disc decompression utilizing Dekompressor. Pain Physician 2009; 12:589-599.

65. Manchikanti L, Derby R, Benyamin RM, Helm S, Hirsch JA. A systematic review of mechanical lumbar disc decompression with nucleoplasty. Pain Physician 2009; 12:561-572.

66. Manchikanti L, Boswell MV, Singh V, Derby R, Fellows B, Falco FJE, Datta S, Smith HS, Hirsch JA. Comprehensive review of neurophysiologic basis and diagnostic interventions in manag. ing chronic spinal pain. Pain Physician 2009; 12:E71-E120.

67. Manchikanti L. Singh V, Datta S, Cohen SP, Hirsch JA. Comprehensive review of epidemiology, scope, and impact of spinal pain. Pain Physician 2009; 12: E35-E70.

68. Boswell MV, Trescot AM, Datta S, Schultz DM, Hansen HC, Abdi S, Sehgal N, Shah RV, Singh V, Benyamin RM, Patel VB, Buenaventura RM, Colson JD, Cordner HJ, Epter RS, Jasper JF, Dunbar EE, Atluri SL, Bowman RC, Deer TR, Swicegood JR, Staats PS, Smith HS, Burton AW, Kloth DS, Giordano J, Manchikanti L. Interventional techniques: Evidencebased practice guidelines in the management of chronic spinal pain. Pain Physician 2007; 10:7-111.

69. Kuslich SD, Ulstrom CL, Michael CJ. The tissue origin of low back pain and sciatica: A report of pain response to tissue stimulation during operation on the lumbar spine using local anesthesia. Orthop Clin North Am 1991; 22:181187.

70. Mixter WJ, Ayers JB. Herniation or rupture of the intervertebral disc into the spinal canal. N Engl J Med 1935; 213:385-395.

71. Pang WW, Mok MS, Lin ML, Chang DP, Hwang MH. Application of spinal pain mapping in the diagnosis of low back pain-analysis of 104 cases. Acta Anaesthesiol Sin 1998; 36:71-74.

72. Manchikanti L, Singh V, Pampati V, Damron KS, Barnhill RC, Beyer CD, Cash KA. Evaluation of the relative contributions of various structures in chronic low back pain. Pain Physician 2001; 4:308-316.
73. Schwarzer AC, Aprill CN, Derby R, Fortin J, Kine G, Bogduk N. The prevalence and clinical features of internal disc disruption in patients with chronic low back pain. Spine (Phila Pa 1976) 1995; 20:1878-1883.

74. Wheeler AH, Murrey DB. Chronic lumbar spine and radicular pain: Pathophysiology and treatment. Curr Pain Headache Rep 2002; 6:97-105.

75. Hadjipavlou AG, Tzermiadianos MN, Bogduk N, Zindrick MR. The pathophysiology of disc degeneration: A critical review. J Bone Joint Surg Br 2008; 90:1261-1270.

76. Ohtori S, Inoue G, Koshi T, Ito T, Doya H, Saito T, Moriya H, Takahashi K. Upregulation of acid-sensing ion channel 3 in dorsal root ganglion neurons following application of nucleus pulposus on nerve root in rats. Spine (Phila Pa 1976) 2006; 31:2048-2052.

77. Aoki Y, Rydevik B, Kikuchi S. Local application of disc-related cytokines on spinal nerve roots. Spine (Phila $\mathrm{Pa}$ 1976) 2002; 27:1614-1617.

78. Norimoto M, Ohtori S, Yamashita M, Inoue G, Yamauchi K, Koshi T, Suzuki M, Orita S, Eguchi Y, Sugiura A, Ochiai N, Takaso M, Takahashi K. Direct application of the TNF-alpha inhibitor, etanercept, does not affect CGRP expression and phenotypic change of DRG neurons following application of nucleus pulposus onto injured sciatic nerves in rats. Spine (Phila Pa 1976) 2008; 33:24032408.

79. Genevay S, Finckh A, Payer M, Mezin F, Tessitore E, Gabay C, Guerne PA. Elevated levels of tumor necrosis factoralpha in periradicular fat tissue in patients with radiculopathy from herniated disc. Spine (Phila Pa 1976) 2008; 33:2041-2046.

8o. Sugiura A, Ohtori S, Yamashita M, Inoue G, Yamauchi K, Koshi T, Suzuki M, Norimoto M, Orita S, Eguchi Y, Takahashi Y, Watanabe TS, Ochiai N, Takaso $M$, Takahashi K. Existence of nerve growth factor receptors, tyrosine kinase $a$ and p75 neurotrophin receptors in intervertebral discs and on dorsal root ganglion neurons innervating intervertebral discs in rats. Spine (Phila Pa 1976) 2008; 33:2047-2051.

81. Yamashita M, Ohtori S, Koshi T, Inoue G, Yamauchi K, Suzuki M, Takahashi K. Tumor necrosis factor-alpha in the nucleus pulposus mediates radicular pain, but not increase of inflammatory peptide, associated with nerve 
damage in mice. Spine (Phila Pa 1976) 2008; 33:1836-1842.

82. Igarashi T, Kikuchi S, Myers RR. Exogenous tumor necrosis factor-alpha mimics nucleus pulposus-induced neuropathology. Molecular, histologic, and behavioral comparisons in rats. Spine (Phila Pa 1976) 2000; 25:2975-2980.

83. Olmarker K, Rydevik B, Nordberg C. Autologous nucleus pulposus induces neurophysiologic and histologic changes in porcine cauda equina nerve roots. Spine (Phila Pa 1976) 1993; 18:14251432.

84. Olmarker K, Blomquist J, Stromberg J. Inflammatogenic properties of nucleus pulposus. Spine (Phila Pa 1976) 1995; 20:665-669.

85. Olmarker K, Myers RR. Pathogenesis of sciatic pain: Role of herniated nucleus pulposus and deformation of spinal nerve root and dorsal ganglion. Pain 1998; 78:99-105.

86. Milette PC, Fontaine S, Lepanto L, Breton $\mathrm{G}$. Radiating pain to the lower extremities caused by lumbar disc rupture without spinal nerve root involvement. AJNR AM J Neuroradiol 1995; 15:1605-1613.

87. Hayashi S, Taira A, Inoue G, Koshi T, Ito T, Yamashita M, Yamauchi K, Suzuki M, Takahashi K, Ohtori S. TNF-alpha in nucleus pulposus induces sensory nerve growth: A study of the mechanism of discogenic low back pain using TNFalpha-deficient mice. Spine (Phila $\mathrm{Pa}$ 1976) 2008; 33:1542-1546.

88. Cummins J, Lurie JD, Tosteson TD, Hanscom B, Abdu WA, Birkmeyer NJ, Herkowitz H, Weinstein J. Descriptive epidemiology and prior healthcare utilization of patients in the Spine Patient Outcomes Research Trial's (SPORT) three observational cohorts: Disc herniation, spinal stenosis, and degenerative spondylolisthesis. Spine (Phila Pa 1976) 2006; 31:806-814.

89. Weinstein JN, Tosteson TD, Lurie JD, Tosteson AN, Blood E, Hanscom B, Herkowitz H, Cammisa F, Albert T, Boden SD, Hilibrand A, Goldberg H, Berven S, An H, SPORT Investigators. Surgical versus nonsurgical therapy for lumbar spinal stenosis. $N$ Engl J Med 2008; 358:794-810.

90. ECRI Health Technology Assessment Group. Treatment of degenerative lumbar spinal stenosis. Evid Rep Technol Assess (Summ) 2001; 32:1-5.

91. Schofferman J, Reynolds J, Herzog R,
Covington E, Dreyfuss P, O'Neill C. Failed back surgery: Etiology and diagnostic evaluation. Spine J 2003; 3:400403.

92. Waguespack A, Schofferman J, Slosar P, Reynolds J. Etiology of long-term failures of lumbar spine surgery. Pain Med 2002; 3:18-22.

93. Waddell G, Kummel EG, Lotto WN, Graham JD, Hall H, McCulloch JA. Failed lumbar disc surgery and repeat surgery following industrial injury. J Bone Joint Surg Am 1979; 61:201-207.

94. Ross JS, Robertson JT, Frederickson RC, Petrie JL, Obuchowski N, Modic MT, de Tribolet N. Association between peridural scar and recurrent radicular pain after lumbar discectomy: Magnetic resonance evaluation. Neurosurgery 1996; 38:855-863.

95. Fritsch EW, Heisel J, Rupp S. The failed back surgery syndrome. Reasons, intraoperative findings, and long-term results: A report of 182 operative treatments. Spine (Phila Pa 1976) 1996; 21:626-633.

96. Manchikanti L. Role of neuraxial steroids in interventional pain management. Pain Physician 2002; 5:182-199.

97. Manchikanti L. Pharmacology of neuraxial steroids. In: Manchikanti L, Singh $\mathrm{V}$ (eds). Interventional Techniques in Chronic Spinal Pain. ASIPP Publishing, Paducah, KY, 2007, pp 167-184.

98. Byrod G, Otani K, Brisby H, Rydevik B, Olmarker K. Methylprednisolone reduces the early vascular permeability increase in spinal nerve roots induced by epidural nucleus pulposus application. J Orthop Res 2000; 18:983-987.

99. Flower RJ, Blackwell GJ. Anti-inflammatory steroid induced biosynthesis of a phospholipase A2 inhibitor which prevents prostaglandin generation. Nature 1979; 278:456-459.

100. Hua SY, Chen YZ. Membrane receptormediated electrophysiological effects of glucocorticoid on mammalian neurons. Endocrinology 1989; 124:687691.

101. Hayashi N, Weinstein JN, Meller ST, Lee HM, Spratt KF, Gebhart GF. The effect of epidural injection of betamethasone or bupivacaine in a rat model of lumbar radiculopathy. Spine (Phila Pa 1976) 1998; 23:877-885.

102. Lee HM, Weinstein JN, Meller ST, Hayashi N, Spratt KF, Gebhart GF. The role of steroids and their effects on phospholipase A2: An animal model of radiculopathy. Spine (Phila Pa 1976) 1998; 23:1191-1196.

103. Minamide A, Tamaki T, Hashizume H, Yoshida M, Kawakami M, Hayashi N. Effects of steroids and lipopolysaccharide on spontaneous resorption of herniated intervertebral discs: An experimental study in the rabbit. Spine (Phila Pa 1976) 1998; 23:870-876.

104. Kingery WS, Castellote JM, Maze M. Methylprednisolone prevents the development of autotomy and neuropathic edema in rats, but has no effect on nociceptive thresholds. Pain 1999; 80:555-566.

105. Kawakami M, Weinstein JN, Chatani K, Spratt KF, Meller ST, Gebhart GF. Experimental lumbar radiculopathy. Behavioral and histologic changes in a model of radicular pain after spinal nerve root irritation with chromic gut ligatures in the rat. Spine (Phila Pa 1976) 1994; 19:1795-1802.

106. Pasqualucci A, Varrassi G, Braschi A, Peduto VA, Brunelli A, Marinangeli $F$, Gori F, Colò F, Paladín A, Mojoli F. Epidural local anesthetic plus corticosteroid for the treatment of cervical brachial radicular pain: Single injection verus continuous infusion. Clin J Pain 2007; 23:551-557.

107. Mao J, Chen LL. Systemic lidocaine for neuropathic pain relief. Pain 2000; 87:7-17.

108. Pasqualucci A. Experimental and clinical studies about the preemptive analgesia with local anesthetics. Possible reasons of the failure. Minerva Anestesiol 1998; 64:445-457.

109. Lavoie PA, Khazen T, Filion PR. Mechanisms of the inhibition of fast axonal transport by local anesthetics. Neuropharmacology 1989; 28:175-181.

110. Bisby MA. Inhibition of axonal transport in nerves chronically treated with local anesthetics. Exp Neurol 1975; 47:481-489.

111. Cassuto J, Sinclair R, Bonderovic M. Anti-inflammatory properties of local anesthetics and their present and potential clinical implications. Acta Anaesthesiol Scand 2006; 50:265-282.

112. Melzack R, Coderre TJ, Katz J, Vaccarino AL. Central neuroplasticity and pathological pain. Ann N Y Acad Sci 2001; 933:157-174.

113. Johnson SM, Saint John BE, Dine AP. Local anesthetics as antimicrobial agents: A review. Surg Infect (Larchmt) 2008; 9:205-213. 
114. Manchikanti L, Singh V, Rivera JJ, Pampati V, Beyer CD, Damron KS, Barnhil RC. Effectiveness of caudal epidural injections in discogram positive and negative chronic low back pain. Pain Physician 2002; 5:18-29.

115. Manchikanti L, Pampati V, Rivera JJ, Beyer CD, Damron KS, Barnhill RC. Caudal epidural injections with sarapin steroids in chronic low back pain. Pain Physician 2001; 4:322-335.

116. Sato C, Sakai A, Ikeda Y, Suzuki H, Sakamoto A. The prolonged analgesic effect of epidural ropivacaine in a rat model of neuropathic pain. Anesth Analg 2008; 106:313-320.

117. Manchikanti L, Damron KS, Cash KA, Manchukonda R, Pampati V. Therapeutic cervical medial branch blocks in managing chronic neck pain: A preliminary report of a randomized, double-blind, controlled trial: Clinical Trial NCTo033272. Pain Physician 2006; 9:333-346.

118. Manchikanti L, Singh V, Falco FJ, Cash KA, Fellows B. Cervical medial branch blocks for chronic cervical facet joint pain: A randomized double-blind, controlled trial with one-year follow-up. Spine (Phila Pa 1976) 2008; 33:18131820.

119. Manchikanti L, Singh V, Falco FJE, Cash KA, Pampati V. Effectiveness of thoracic medial branch blocks in managing chronic pain: A preliminary report of a randomized, double-blind controlled trial; Clinical trial NCT00355706. Pain Physician 2008; 11:491-504.

120. Tachihara H, Sekiguchi M, Kikuchi S, Konno S. Do corticosteroids produce additional benefit in nerve root infiltration for lumbar disc herniation. Spine (Phila Pa 1976) 2008; 33:743-747.

121. Lewandowski EM. The efficacy of solutions used in caudal neuroplasty. Pain Digest 1997; 7:323-330.

122. Aldrete JA, Zapata JC, Ghaly R. Arachnoiditis following epidural adhesiolysis with hypertonic saline report of two cases. Pain Digest 1996; 6:368-370.

123. Manchikanti L, Bakhit CE. Removal of torn Racz catheter from lumbar epidural space. Reg Anesth 1997; 22:579581.

124. Kim RC, Porter RW, Choi BH, Kim SW. Myelopathy after intrathecal administration of hypertonic saline. Neurosurgery 1988; 22:942-944.
125. Hitchcock ER, Prandini MN. Hypertonic saline in management of intractable pain. Lancet 1973; 1:310-312.

126. Lucas JS, Ducker TB, Perot PL. Adverse reactions to intrathecal saline injections for control of pain. I Neurosurg 1975; 42:557-561.

127. Dagi TF. Comments on myelopathy after the intrathecal administration of hypertonic saline. Neurosurgery 1988; 22:944-945.

128. Lundy JS, Essex HE, Kernohan JW. Experiments with anesthetics. IV. Lesions produced in the spinal cord of dogs by a dose of procaine hydrochloride sufficient to cause permanent and fatal paralysis. JAMA 1936; 101:1546-1550.

129. Rojiani AM, Prineas JW, Cho ES. Electrolyte-induced demyelination in rats. Ultrastructural evolution. Acta Neuropathol (Berl) 1994; 88:293-299.

130. Rojiani AM, Prineas JW, Cho ES. Protective effect of steroids in electrolyte-induced demyelination. J Neuropathol Exp Neurol 1987; 46:495-504.

131. Lake DA, Barnes CD. Effects of changes in osmolality on spinal cord activity. Exp Neurol 1980; 68:555-567.

132. Abram SE, O'Connor TC. Complications associated with epidural steroid injections. Reg Anesth 1996; 212:149-162.

133. Nelson DA. Intraspinal therapy using methylprednisolone acetate. Spine (Phila Pa 1976) 1993; 18:278-286.

134. Kushner FH, Olson JC. Retinal hemorrhage as a consequence of epidural steroid injection. Arch Ophthalmol 1995; 113:309-313.

135. Sampath P, Rigamonti D. Spinal epidural abscess: A review of epidemiology, diagnosis, and treatment. J Spinal Disord 1999; 12:89-93.

136. Bromage PR. Complications and contraindications. In: Bromage PR (ed). Epidural Analgesia. WB Saunders, Philadelphia, 1978, pp 469-471.

137. Bromage PR, Benumof JL. Paraplegia following intracord injection during attempted epidural anesthesia under general anesthesia. Reg Anesth Pain Med 1998; 23:104-107.

138. Manchikanti L, Pampati V, Beyer C, Damron KS, Cash KA, Moss TL. The effect of neuraxial steroids on weight and bone mass density: A prospective evaluation. Pain Physician 2000; 3:357366.
139. Moher D, Schulz KF, Altman D, for the CONSORT Group. The CONSORT statement: Revised recommendations for improving the quality of reports of parallel-group randomized trials. JAMA 2001; 285:1987-1991.

140. Piaggio G, Elbourne DR, Altman DG, Pocock SJ, Evans SJ. Reporting of noninferiority and equivalence randomized trials: An extension of the CONSORT statement. JAMA 2006; 295:1152-1160.

141. Manchikanti L, Hirsch JA, Smith HS. Evidence-based medicine, systematic reviews, and guidelines in interventional pain management: Part 2: Randomized controlled trials. Pain Physician 2008; 11:717-773.

142. Manchikanti L, Benyamin RM, Helm S, Hirsch JA. Evidence-based medicine, systematic reviews, and guidelines in interventional pain management: Part 3: Systematic reviews and meta-analysis of randomized trials. Pain Physician 2009; 12:35-72.

143. Fairbank JCT, Pynsent PB. The Oswestry disability index. Spine (Phila Pa 1976) 2000; 25:2940-2953.

144. Manchikanti L, Singh V, Smith HS, Hirsch JA. Evidence-based medicine, systematic reviews, and guidelines in interventional pain management: Part 4: Observational studies. Pain Physician 2009; 12:73-108.

145. Manchikanti L, Datta S, Smith HS, Hirsch JA. Evidence-based medicine, systematic reviews, and guidelines in interventional pain management: Part 6: Systematic reviews and meta-analyses of observational studies. Pain Physician 2009; 12:819-850.

146. Pereira J, Lawlor P, Vigano A, Dorgan M, Bruera E. Equianalgesic dose ratios for opioids. A critical review and proposals for long-term dosing. J Pain Symptom Manage 2001; 22:672-687.

147. Browner WS, Newman TB, Cummings SR, Hulley SB. Estimating sample size and power. In: Hulley SB, Cummings SR, Browner WS, Grady D, Hearst N, Newman TB (eds). Designing Clinical Research: An Epidemiologic Approach, 2nd ed. Lippincott, Williams \& Wilkins, Philadelphia, 2001, pp 65-84.

148. Koes BW, Scholten RJ, Mens JM, Bouter LM. Efficacy of epidural steroid injections for low-back pain and sciatica: A systematic review of randomized clinical trials. Pain 1995; 63:279-288. 


\section{APPENDIX I \\ Protocol for Evaluation of the Comparative Effectiveness of Percutaneous Adhesiolysis and Caudal Epidural Steroid Injections in Low Back and/or Lower Extremity Pain without Post Surgery Syndrome or Spinal Stenosis: A Randomized, Equivalence Trial of Percutaneous Lumbar Adhesiolysis and Caudal Epidural Steroid Injections}

\section{Technique}

Prior to undergoing adhesiolysis, all patients will be assessed with a comprehensive physical and psychological evaluation. All less invasive and conservative modalities of treatment, including fluoroscopically directed epidural steroid injections, should be exhausted. In addition, appropriate laboratory studies should be considered to rule out bleeding disorders. Anticoagulants should be discontinued to avoid unusual bleeding.

Procedure Environment: The procedure is performed in a sterile operating room under appropriate sterile precautions utilizing fluoroscopy.

Preparation: After the initial evaluation, the patient is transferred to the holding area where appropriate preparation is carried out with preoperative evaluation, checking of vital signs and establishment of intravenous access as well as antibiotic administration.

Consent: An appropriate detailed consent is obtained from all the patients.

Operating Room: The procedure will include appropriate preparation with intervenous access, antibiotic administration, and appropriate sedation.

An RK needle will be introduced into the sacral epidural space under intermittent fluoroscopy. Once the needle placement is confirmed to be in the epidural space, a lumbar epidurogram will be carried out, utilizing approximately $5 \mathrm{~mL}$ of contrast (Omnipaque® 240). Identification of the filling defects will be carried out by examining the contrast flow into the nerve roots. Intravascular or subarachnoid placement of the needle or contrast will be avoided; if such malpositioning occurs, the needle will be repositioned.

In Group I, after the epidurography, a Racz catheter will be passed through the RK needle up to S3 and additional Omnipaque $240,3 \mathrm{~mL}$, will be injected. Following this, $5 \mathrm{~mL}$ of $2 \%$ preservative-free Xylocaine will be injected into the epidural space through the catheter.

In Group II, after identification of the filling defects, the Racz catheter will be advanced through the RK needle to the area of filling defect or the site of pathology as determined by MRI, CT, or symptomatology.

Adhesiolysis will be carried out and the final positioning will be achieved in the epidural space laterally and ventrally. After satisfactory positioning, at least $3 \mathrm{~mL}$ of contrast will be injected. If there is no subarachnoid, intravascular, or other extra epidural filling and satisfactory filling is obtained with epidural and targeted nerve root filling, $5 \mathrm{~mL}$ of $2 \%$ preservative-free Xylocaine will be injected either as a single dose in patients without hardware or fusion or will be injected intermittently in other cases. 


\title{
APPENDIX II \\ Informed Consent to Participate in a Clinical Research Study
}

\section{Study Title: Protocol for evaluation of the comparative effectiveness of percutaneous adhesiolysis and caudal epidural steroid injections in low back and/or lower extremity pain without post surgery syndrome or spinal stenosis: A randomized, equivalence trial of percutaneous lumbar adhesiolysis and caudal epidural steroid injections}

\author{
Principal Investigator: Laxmaiah Manchikanti, MD \\ Study Site: $\quad$ Ambulatory Surgery Center
}

This consent form may contain words that you do not understand. Please ask the study doctor or the study staff to explain any words or information that you do not clearly understand.

\section{Introduction}

The following information will describe the study and your role as a participant. This document is intended to inform you about the nature and risks of the clinical study in which you have been invited to participate. The principal investigator or a member of the study team will answer any questions you may have about this consent form and about the study. Please read this consent form carefully and do not hesitate to ask any questions you may have about the information provided below.

\section{Description and Purpose of the Study}

You have been invited to take part in this research study because you have been diagnosed with chronic low back pain, and previous treatment with fluoroscopically directed epidural injections has failed.

This is a randomized double-blind study which means that both you and the study doctor will not know which treatment is provided.

A total of 120 patients will be studied in 2 groups with 60 patients in each group: Group I will receive caudal epidural injections with catheterization up to S3 with local anesthetic, steroids, and $0.9 \%$ sodium chloride solution; Group II will receive percutaneous adhesiolysis with targeted delivery of lidocaine, 10\% hypertonic sodium chloride solution, and non-particulate betamethasone.

\section{Objectives of This Study}

1) To evaluate the effectiveness of percutaneous epidural adhesiolysis in managing chronic low back and/or lower extremity pain in patients without post lumbar surgery syndrome or spinal stenosis and compare with fluoroscopically directed caudal epidural steroid injections.

2) To evaluate and compare the adverse event profile in all groups.

\section{Study Procedures}

All patients will be unblinded at 12 months.

\section{LeNGTH OF THE STUdY}

Patients will return for follow-up visits at 3, 6, 12, 18, and 24 months post-treatment. The recruitment period is estimated as 24 months with an anticipated study duration of 48 months. 


\section{APPENDIX II (cont.) \\ Evaluations}

Evaluations will be conducted prior to starting the study procedures and each follow-up time at 3, 6, 12, 18, and 24 months. These evaluations will include pain evaluation, disability questionnaire, medication use, and employment status.

\section{Risk/benefit Analysis}

Percutaneous adhesiolysis with or without hypertonic saline neurolysis, like any invasive procedure, poses potential risks and/or complications. Risks or complications associated with adhesiolysis procedure using the Racz catheter include but are not limited to: transient post-operative pain; sensory or motor deficit; and in rare instances, neural trauma, subarachnoid blockade, epidural hematoma, steroid side effects, infection, or neurologic injury.

The anticipated benefits to subjects with chronic low back pain who participate in this study include: 1) amelioration of chronic back pain without the risks of major surgery or general anesthesia, and 2) subjects may also have an improvement in function and quality of life as a result of the diminution in pain. In addition, the information gained from this investigation may help to improve the future developments of minimally invasive techniques for treating chronic low back pain.

The risks involved with this procedure include, but are not limited to, numbness, weakness, reaction to local anesthetics, steroids, and/or other medications, dural puncture with subsequent complications, hematoma formation, urinary retention, muscle spasm, and increase in pain following injection therapy, injection into the blood vessels or around the spinal cord with complications, and infection.

Other consequences include failure of the procedure to be effective and also increased levels of pain.

\section{Discontinuation of the Study}

You may discontinue or withdraw from the study for the following reasons:

1. You may like to withdraw prematurely from the study.

2. You want to proceed to another nonsurgical or surgical intervention such as spinal endoscopy or surgery.

3. Investigator's judgment.

4. A complication directly related to the procedure or device that requires withdrawal from the study.

\section{Pregnancy and Breastfeeding (For Women Omly)}

Pregnant women and nursing mothers will not be allowed to enter this study. Women who are at least 2 years postmenopausal, sterilized, or who are willing to use a medically acceptable form of birth control (e.g., oral or implanted contraceptive, IUDs, sterilization, or barrier plus spermicide) may participate in this study; women who can become pregnant and who are not using a medically acceptable form of birth control may not participate in this study.

If you suspect you are pregnant at any time during the study, you must notify your study doctor immediately. If you become pregnant, no further procedures will be performed. It is important that you do not participate in the study if you have a positive pregnancy test or if you think you may be pregnant. If you plan to become pregnant during the course of this study, you should not enroll in the study. By signing this document, you are agreeing not to become pregnant while participating in the study.

The effects of drugs and procedures on human fetuses are unknown and may be harmful. In addition, x-rays may be harmful.

If you do become pregnant during your participation in this study, all costs for care related to your pregnancy, childbirth, and postpartum/ newborn care will be your responsibility. However, you should provide all information in follow-up.

\section{Special Precautions}

You should exercise special caution when driving or using machinery for 24 hours after the procedure due to sedation.

\section{Benefits Of The Study}

There is no guarantee of benefit as a result of your participation in this study. You may or may not respond to treatment with the study procedure. Taking part in this study may reduce the severity of your symptoms; however, you may experience either no improvement or a worsening of your condition. Future patients may, however, benefit from the overall conclusions drawn from the results of the study.

\section{New Information}

As with any procedure, there is the possibility of complications and undesirable side effects which are unknown at this time and could possibly occur. You will be told of any significant new findings that develop during the course of this study that may affect your willingness to continue your participation. 


\section{APPENDIX II (cont.) \\ Alternative Treatment}

You understand that if you do not wish to participate in this study, there are other procedures available for treatment of chronic low back pain. Standard treatments include non-drug therapies (physical therapy, chiropractic manipulation, acupuncture, TENS, laser therapy, and surgery), drug treatments including anti-inflammatories (NSAIDs), muscle relaxants, narcotic analgesics, antidepressants, anti-seizure medications, steroids, and other procedures such as epidural steroid injections. However, you have determined that these have failed in the past. If you withdraw your participation or if you are terminated, the study doctor will recommend an alternative treatment for your condition. You do not have to participate in this study to receive treatment for your condition.

\section{Participation Information}

Your participation in this study is voluntary. You may refuse to participate or you may discontinue participation at any time during the study without penalty or loss of benefits to which you are otherwise entitled. If you wish to voluntarily withdraw from the study, please notify your study doctor immediately and arrange for a final visit.

\section{Confidentiality}

Every reasonable effort will be made to keep your medical records confidential.

\section{Persons To Contact}

If you have any questions about this study or your rights, please call Dr. Manchikanti or the study staff at (270) 554-8373, Ambulatory Surgery Center, 2831 Lone Oak Road, Paducah, KY 42003.

\section{Consent}

I have read or someone has read this informed consent to me in a language I can understand. I have fully discussed and understand the purpose and procedures of this study which have been explained to me, in a layman's language. I have been given the chance to ask any questions that I have about the study, and all my questions have been answered to my satisfaction. I acknowledge that I will be given a signed copy of this consent form.

Having thoroughly read and understood all of the above information, I voluntarily agree to participate in this research study. I understand that I have not given up any of my legal rights by signing this informed consent.

Printed Name of Study Participant

Signature of Study Participant

Date

Printed Name of Witness

Signature of Witness

Date

To the best of my knowledge, the information contained in this document was fully and carefully explained to the study participant.

Printed Name of Investigator or Designee

Signature of Investigator or Designee

Date 